\title{
Сухоняк С.O.
}

\section{ОПТИМІЗУВАННЯ ВИТРАТ РЕСУРСІВ ПІДПРИЕМСТВ ШЛЯХОМ ЗАЛУЧЕННЯ ДО СПІВПРАЦІ АУТСОРСИНГОВИХ КОМПАНІЙ}

\begin{abstract}
Розроблено оптимізаційну модель, яка дає змогу мінімізувати втрати та витрати ресурсів, необхідних для ефективної діяльності як замовника послуг, так $і$ провайдера, а також забезпечити результативність прочесу передачі бізнес-прочесів від замовника до провайдера послуг. Насамперед автор пропонує оптимізувати використання трудових ресурсів як основних в діяльності сучасного підприємства. Таке оптимізування також дає змогу ефективно використати наявні ресурси та створити умови для розвитку лідерів та персоналу загалом. Окрім оптимізації діяльності замовника аутсорсингу також повинен бути оптимізований сам прочес передачі функиій від замовника до провайдера, при ичьому оптимізація повинна відбутися за основними видами ресурсів, насамперед людськими, часовими та фінансовими.
\end{abstract}

Ключові слова: оптимізування ресурсів, аутсорсинг, провайдер,машинобудівне підприємство.

Постановка проблеми. Дослідження, які проводились та виконувались на різних ринках та галузях, і власне наше дослідження чітко засвідчують тенденцію домінування однієї причини використання аутсорсингу, а саме оптимізування витрат ресурсів в процесі виробничо-господарської діяльності. Доцільність оптимізування зумовлюється використанням стратегій лідерства за витратами, фокусування на низьких витратах або оптимальних витрат. Передумовою успішної реалізації таких стратегій є побудова ланцюжка із низькими операційними та трансакційними витратами, який у сучасній світовій економіці може бути сформований виключно на засадах розвитку аутсорсингу.

Аутсорсинг в таких ланцюжках та стратегіях дає переваги не тільки виробнику, постачальнику чи посереднику, а насамперед кінцевому споживачу продукції, що має змогу отримати продукт дешевший або вищої якості iз додатковими сервісними послугами тощо, тобто із вищою споживчою цінністю. Крім того, побудова виробничо-господарських ланцюжків продукування товарів чи послуг із використанням аутсорсингу дає змогу вирішувати і низку соціально-економічних та екологічних проблем регіонів, локацій чи країн.

Аналіз останніх досліджень та публікацій. Поняття "аутсорсинг" (“outsourcing”) є англомовного походження, а точніше скороченням англійського терміну "outside source using", що означає

(C) Сухоняк Софія Омелянівна, асистент кафедри економіки підприємства, Національного лісотехнічного університету України, тел.:+380675834226, e-mail: sofiasuh @ukr.net застосування (використання) зовнішніх джерел або ресурсів [1]. Виник цей термін у практичній діяльності на початку 60 років минулого століття, а саме - у 1962 р., коли було засновано Electronic Data System Corporation (EDS) [2, c. 11].

Одним із найбільш цитованішим у вітчизняних наукових працях, присвяченим проблемам аутсорсингу, визначенням $\epsilon$ те, що це явище, яке полягає у “реалізації окремих функцій або бізнес-процесів зовнішньою організацією, яка володіє необхідними для цього ресурсами, на основі довгострокової угоди" [3]

Дж. Кросс доходить висновку, що встановивши конкретні цілі та визначившись iз формою аутсорсингу, підприємство фактично таким чином формує індивідуальну стратегію управління із елементами аутсорсингу [4].

Вітчизняні науковці підтримують стратегічну спрямованість аутсорсингу як інструменту підвищення рівня конкурентоспроможності організації через фокусування іii діяльності на ключових, компетенціях, завдання, функціях та/або бізнес-процесах [2, с. - 112].

Також зазначають, що аутсорсинг спрямований на підвищення виробничої ефективності фірми шляхом скорочення витрат, формування гнучкості для адаптування до динамічного середовища, забезпечення належної якості продуктам, уникнення або зниження рівня ризиків [5]. Дослідження промислових підприємств показало, що аутсорсинг це спосіб розвитку та вдосконалення коопераційних виробничих відносин між суб'єктами в ринкових умовах [6]. При використанні аутсорсингу як 
маркетингового інструменту передбачається "можливість передачі всіх або ж частини маркетингових функцій іншій фірмі, яка спеціалізується на виконанні певного виду робіт у цій сфері" [7].

При цьому залишається недосліджене питання використання оптимізаційних моделей для зниження витрат .

Оптимізаційні моделі передбачають знаходження оптимального значення обраної функції на допустимій множині значень [8; 9]. Як зазначають науковці, задачі оптимізації бувають двох типів - задача максимізації або мінімізації. При цьому розв'язок будь якої оптимізаційної моделі незалежно від іiі виду передбачає ідентифікування іiі екстремуму або визначення відсутності розв'язків за встановленої сукупності обмежень.

Формулювання цілей статті. Створити моделі оптимізування витрат ресурсів підприємств шляхом залучення до співпраці аутсорсингових компаній та провести тестування такої моделі.

Опис основного матеріалу досліджень. Побудова оптимізаційної моделі слід розпочати із формування функції мети, в якій повинна бути встановлена одиниця ефективності або обчислювальний індикатор. Серед найчастіше обраних індикаторів зустрічаються: одиниця виготовленої продукції або наданих послуг, різні види витрат підприємств, втрати, одиниця прибутку, витрат певного ресурсу (часу, інформації, енергії тощо) чи засобу виробництва тощо. Отже в залежності від стратегіï, цілей та виду аутсорсингу оптимізація може відбуватись за видами ресурсів, на яких здійснюється економія або нарощування прибутку чи інших позитивних ефектів. Виходячи iз вищенаведених досліджень, найчастіше цілями оптимізації $\epsilon$ зниження витрат. Тому функція мети можна записати наступним чином.

$$
F(d x) \rightarrow \min
$$

$x$ - витрати на одну функцію або бізнеспроцес;

$d$ - функції або бізнес-процеси, передані замовником на виконання провайдеру.

Оптимізаційні моделі важливі для підприємств замовників, оскільки не завжди доцільно повністю скорочувати бізнеспроцес, а віддавати лише його частину, або частину працівників i залишити в себе принаймні на певну кількість годин власного працівника для внутрішньої підтримки бізнеспроцесу, захисту комерційних та корпоративних інтересів, узгодження та інтеграції виробничо-господарської діяльності провайдера та замовника аутсорсингу тощо.

Витрати при цьому доцільно поділяти за видами використаних ресурсів, а саме на: матеріальні, фінансові, інформаційні, людські та часові. При формуванні вхідних статистичних даних для знаходження розв'язків оптимізаційних моделей важливо чітко розмежувати ресурсні витрати між собою, оскільки фактично всі види ресурсів можуть відобразитись у вартісній формі тобто можуть бути переведені у фінансові результати. Уникнувши такої помилки, можна чітко отримати не тільки оптимальні обсяги витрат ресурсів але й оптимальну структуру ресурсів у виробничо-господарській діяльності замовника аутсорсингу. Відповідно поділивши ресурси на вище перелічені, отримаємо наступну модель:

$$
\sum_{i=1}^{n} \operatorname{di}\left(x_{1}+x_{2}+x_{3}+x_{4}+x_{5}\right) \rightarrow \min (2)
$$

де $d_{i}$ - функції або бізнес-процеси, які передаються до виконання провайдером

$x_{1}$ - витрати матеріальних ресурсів на виконання бізнес-процесів;

$x_{2}$ - витрати людських ресурсів на виконання бізнес-процесів;

$x_{3}$ - витрати фінансових ресурсів на виконання бізнес-процесів;

$x_{4}$ - витрати інформаційних ресурсів на виконання бізнес-процесів;

$x_{5}$ - витрати часових ресурсів на виконання бізнес-процесів.

Аналіз застосування такої оптимізаційної моделі показує, що можна оптимізувати ресурси за кожним із окремих бізнеспроцесів, які передаються до провайдера, або оптимізувати один ресурс для усіх бізнеспроцесів. При цьому витрати на ресурси повинні бути презентовані як два індикатори: витрати на ресурси $(y)$ та обсяг використаних ресурсів $(x)$. Відповідно функція оптимізування за одним ресурсом матиме такий вигляд:

$$
\sum_{i=1}^{n} \operatorname{diyi}\left(x_{1}+x_{2}+x_{3}+x_{4}+x_{5}\right) \rightarrow \min .
$$

Модель для оптимізування витрат за одним бізнес-процесом матиме вигляд:

$$
\begin{gathered}
x_{1} y_{1}+x_{2} y_{2}+x_{3} y_{3}+x_{4} y_{4}+x_{5} y_{5} \rightarrow \min ,(4) \\
\text { де } y_{1}-\text { обсяг матеріальних ресурсів, які }
\end{gathered}
$$
необхідні для виконання аналізованого бізнеспроцесу;

$y_{2}-$ обсяг людських ресурсів, необхідних для виконання аналізованого бізнес-процесу; 
$y_{3}$ - обсяг фінансових ресурсів, необхідних для виконання аналізованого бізнес-процесу;

$y_{4}-$ обсяг інформаційних ресурсів, необхідних для виконання аналізованого бізнес-процесу;

$y_{5}$ - обсяг часових ресурсів, необхідних для виконання аналізованого бізнес-процесу.

Доцільність вибору однієї або іншої моделі залежить від особливостей підприємства, схожості бізнес-процесів та пов'язаності між собою, наявності синергічних ефектів між функціями чи бізнес-процесами, наявністю ризиків бізнес-процесів, а найголовніше схожістю структури витрат кожного бізнеспроцесу.

Одні підприємства починають співпрацю із передачі одного бізнес-процесу, а пізніше при

\begin{tabular}{|c|}
\hline 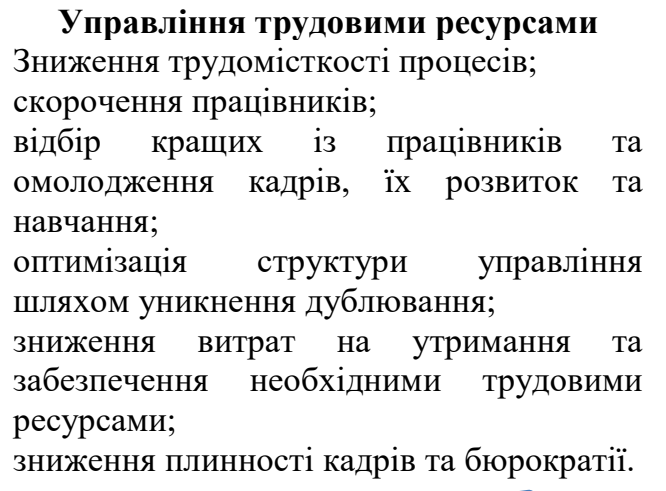 \\
\hline
\end{tabular}

якісному виконання угоди провайдером переходить до передачі декількох бізнеспроцесів. Тому розглянемо ситуацію з позиції оптимізування ресурсів при передачі одного бізнес-процесу. Для цього слід розробити обмеження для оптимізаційної моделі, виходячи із встановлених цілей та наявного потенціалу підприємства, а також політики управління ресурсами. Аналізування діяльності підприємств дає змогу виокремити такі основні аспекти, які слід сформалізувати у системі обмежень до оптимізаційної моделі. Сруктурно обмеження до розробленої оптимізаційної моделі можна подати на рис. 1.

\section{Управління часовими ресурсами}

Зниження та уникнення непродуктивних втрат робочого часу працівниками;

узгодження графіків роботи між підрозділами, провайдером та замовником аутсорсингу;

впровадження та використання методів тайм-менеджменту в управлінській діяльності;

використання інструментів гнучкості та адаптивності графіків роботи, які домінують у сучасному менеджменті.

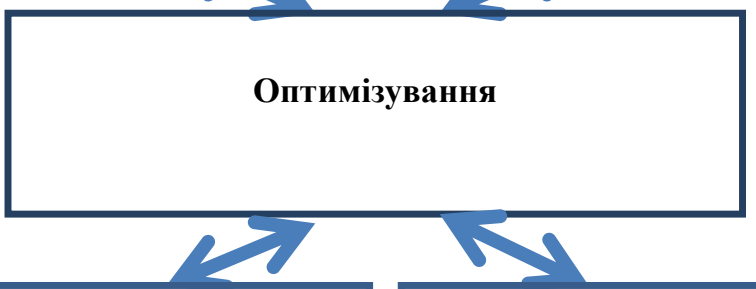

Управління матеріальними ресурсами мінімізація втрат матеріальних та енергетичних ресурсів в процесі транспортування, виробництва та зберігання;

належна якість постачання матеріальних ресурсів;

скорочення матеріаломістких процесів i перенесення їх до провайдера;

підвищення оборотності ресурсів;

зменшення кількості матеріальних ресурсів та витрат на їх утримання.
Управління інформаційними ресурсами

Здобуття адекватних та вчасних ресурсів 3 метою підвищення ефективності прийняття управлінських рішень;

зниження рівня дезінформації та шуму, а також помилкових рішень;

розвиток комунікаційних зв'язків та ефективності комунікацій;

застосування сучасних методів обробки інформації та формування баз даних для прийняття управлінських рішень.

\section{Рис. 1. Цілі та завдання оптимізування ресурсів підприсмства при передачі бізнес- процесів на аутсорсинг* \\ * Сформовано автором}

Відповідно усі наведенї вище на рисунку цілі та завдання можна представити математично у вигляді обмежень. Наведемо приклад найдоцільніших обмежень при дослідженні аутсорсингу в розрізі оптимізації використання ресурсів та підвищення результативності їх застосування у виробничо-господарській діяльності підприємства. Наприклад обмеження по 
витратах на розвиток та навчання персоналу можна записати наступним чином:

$$
g_{1} y_{1}+g_{2} y_{2}+g_{3} y_{3}+\ldots g_{i} y_{i} \leq G
$$

де $g_{1}, g_{2}, g_{3}, g_{n}-$ витрати на розвиток та навчання персоналу різних бізнес-процесів, аналізованих для передачі на аутсорсинг;

$i$ - кількість бізнес-процесів;

$G$ - обсяг фонду передбаченого на навчання та розвиток персоналу.

Також важливим $\epsilon$ обмеження по непродуктивній втраті часу (запізнення на роботу, вирішення власних справ працівниками під час робочого часу, нерегламентовані перерви у роботі тощо), які можна формалізувати наступним чином:

$$
t_{1} y_{1}+t_{2} y_{2}+t_{3} y_{3}+\ldots t_{i} y_{i} \leq T
$$

$t_{1}, t_{2}, t_{3}, t_{i}-$ непродуктивні втрати робочого часу працівників різних бізнес-процесів;

$T$ - максимально можливі втрати робочого часу протягом певного періоду за аналізованими бізнес-процесами.

Сформуємо обмеження за матеріальними ресурсами для окремих бізнес-процесів, а точніше вказавши основні із них постачання, зберігання та використання у виробничо-господарській діяльності підприємств. Відповідно, взявши до уваги три виокремлені бізнес-процеси, формалізоване обмеження матиме вигляд:

$$
p_{1} r_{1}+p_{2} r_{2}+p_{3} r_{3} \leq R
$$

$p_{1,} p_{2}, p_{3}-$ вартість матеріальних ресурсів аналізованих бізнес-процесів (постачання, зберігання та використання);

$r_{1}, r_{2}, r_{3}$ - обсяг втрат матеріальних ресурсів за кожним відповідно аналізованим бізнес-процесом (постачання, зберігання та використання);

$R$ - допустимий обсяг втрат матеріальних ресурсів підприємства.

Для прийняття управлінських рішень необхідно володіти повною інформацією, що відповідно знижує рівень ризиків прийняття помилкових та неадекватних рішень. На практиці усі рішення приймаються 3 різним рівнем ризику, тобто управлінець ніколи не здатен володіти усією інформацією, оскільки на здобуття додаткової інформації потрібно витрачати ресурси, також обробка та аналізування інформації, відбір для кожного управлінського рішення вимагає витрачання значних ресурсів. Тому завжди існує обмеження ресурсів для управління інформацією i це формалізовано можна зобразити у вигляді нерівності наступним чином:

$$
z_{1} o_{1}+z_{2} o_{2}+z_{3} o_{3} \leq Z
$$

$z_{1}, z_{2}, z_{3}$ - витрати на збір, обробку та захист інформаційних ресурсів відповідно;

$o_{1}, o_{2}, o_{3}-$ обсяг інформації, яку необхідно зібрати, обробити та захистити від витоку відповідно;

$\mathrm{Z}$ - обсяг ресурсів для збору, оброблення та захисту інформації.

Найчастіше оптимізування 3 метою передачі певних функцій чи бізнес-процесів в аутсорсинг здійснюється, насамперед для скорочення витрат на отримання персоналу різних підрозділів. Тому сформуємо таку оптимізаційну модель скорочення витрат за одним видом ресурсів для різних підрозділів або бізнес-процесів.

$$
d_{1} y_{1}+d_{2} y_{2}+d_{3} y_{3} \rightarrow \min ,
$$

де $d_{1}, d_{2}, d_{3}$ - обсяг витрат на персонал у аналізованих бізнес-процесах (налагодження та оснастка обладнання, системне адміністрування, маркетинг та сервісна підтримка);

$y_{1}, y_{2}, y_{3}-$ річна середньоспискова чисельність працівників за аналізованими бізнес-процесами.

Обмеження можна робити за різними видами витрат, які необхідні для управління людськими ресурсами. Зокрема вітчизняними авторами запропоновано розглядати обмеження щодо наступних витрат: на заробітну плату, матеріальні витрати на забезпечення діяльності працівників, амортизацію обладнання та техніку, необхідну для діяльності персоналу, відрахування у соціальні фонди та інші витрати на утримання та забезпечення діяльності персоналу [9].

Такий підхід ефективний за умови стабільності за структурою та складом персоналу та мінімального рівня плинності кадрів. При плинності кадрів важко чітко зафіксувати витрати за виділеними групами, оскільки постійно зявлятимуться витрати, пов'язані із наймом, навчанням, розвитком, звільненням персоналу, визначенням потреби у новому персоналі, адміністративні витрати тощо. Тому витрати на людські ресурси доцільніше згрупувати за основними функціями управління персоналом, а саме: добір персоналу та організування його роботи, адаптація та розвиток, мотивація персоналу, звільнення, в тому числі і захист комерційної таємниці, пов'язаної із звільненням працівників. 
Використавши останнє наведене групування витрат, сформовано відповідно систему обмежень:

$$
\left\{\begin{array}{l}
j_{1} y_{1}+m_{1} y_{1}+n_{1} y_{1}+g_{1} y_{1} \leq \psi_{1} \\
j_{2} y_{2}+m_{2} y_{2}+n_{2} y_{2}+g_{2} y_{2} \leq \psi_{2} \\
j_{3} y_{3}+m_{3} y_{3}+n_{3} y_{3}+g_{3} y_{3} \leq \psi_{3} \\
j_{4} y_{4}+m_{4} y_{4}+n_{4} y_{4}+g_{4} y_{4} \leq \psi_{4}
\end{array}\right.
$$

де $j_{1}, j_{2}, j_{3}, j_{4}-$ витрати на добір персоналу та організування його роботи за такими бізнеспроцесами відповідно: налагодження та адміністрування, маркетинг та сервісна підтримка;

$m_{1}, m_{2}, m_{3}, m_{4}-$ витрати на адаптацію та розвиток персоналу за бізнес-процесами відповідно: налагодження та оснастка обладнання, системне адміністрування, маркетинг та сервісна підтримка;

$n_{1}, n_{2}, n_{3}, n_{4} \quad$ - витрати на мотивацію персоналу за бізнес-процесами: налагодження та оснастка обладнання, системне адміністрування, маркетинг та сервісна підтримка;

$g_{1}, g_{2}, g_{3}, g_{4}-$ витрати на звільнення персоналу у бізнес-процесах: налагодження та оснастка обладнання, системне адміністрування, маркетинг та сервісна підтримка;

Також додатковим обмеженням має бути витрати на сплату за послуги провайдера. Окрім того, для стабільного виконання бізнеспроцесів певна кількість працівників повинна залишитись у замовника 3 метою мінімізації ризиків інтеграції та узгодження діяльності, захист корпоративних інтересів тощо, тому будуть мінімальні обсяги витрат забезпечення кожного із аналізованих бізнес-процесів: оснастка обладнання, системне

$$
\left\{\begin{array}{l}
\alpha_{1} \leq j_{1} y_{1}+m_{1} y_{1}+n_{1} y_{1}+g_{1} y_{1} \leq \psi_{1} \\
\alpha_{2} \leq j_{2} y_{2}+m_{2} y_{2}+n_{2} y_{2}+g_{2} y_{2} \leq \psi_{2} \\
\alpha_{3} \leq j_{3} y_{3}+m_{3} y_{3}+n_{3} y_{3}+g_{3} y_{3} \leq \psi_{3} \\
\alpha_{4} \leq j_{4} y_{4}+m_{4} y_{4}+n_{4} y_{4}+g_{4} y_{4} \leq \psi_{4}
\end{array}\right.
$$

де

$\alpha_{1}, \alpha_{2}, \alpha_{3}, \alpha_{4}$ - мінімальний обсяг витрат, необхідний для ефективної роботи підприємства-замовника аутсорсингу за бізнес-процесами: налагодження та оснастка обладнання, системне адміністрування, маркетинг та сервісна підтримка.

Дані для розрахунку моделі слід брати із фінансового плану при передачі бізнеспроцесів провайдеру для ПрАТ «КонцернЕлектрон».

Аналізування діяльності ПрАТ «КонцернуЕлектрон» показав про доцільність перенесення працівників із зазначених вище підрозділів. Зокрема доцільно перенести на провайдерів частину виконуваної роботи i відповідно частину персоналу. Тому значення для оптимізаційної моделі взято із бухгалтерської звітності та планів розвитку аутсорсингової діяльності (табл. 1).

Підставивши усі дані в теоретичну модель, отримаємо систему нерівностей:

$214934 y_{1}+96092 y_{2}+198120 y_{3} \rightarrow \min$,

$\left\{\begin{array}{l}644814 \leq 214934 y_{1} \leq 2127845 \\ 1921867 \leq 96092 y_{2} \leq 1311665(13) \\ 792488, \leq 198120 y_{3} \leq 3002671\end{array}\right.$

Таблиця 1

Дані для формування оптимізаційної моделі ПрАТ «Концерну-Електрон» [10]

\begin{tabular}{|l|c|}
\hline \multicolumn{1}{|c|}{ Індикатори } & $\begin{array}{c}\text { Кількісні } \\
\text { вимірники }\end{array}$ \\
\hline Середні витрати на одного працівника для налагодження та оснастки обладнання в рік, грн. & 214934 \\
\hline Середні витрати на одного системного адміністратора в рік, грн. & 96092 \\
\hline Середні витрати на одного працівники залученого до маркетингу та підтримки продукції в рік, грн. & 198120 \\
\hline $\begin{array}{l}\text { Мінімальний обсяг витрат, необхідний для ефективного налагодження та оснастки обладнання, } \\
\text { грн. }\end{array}$ & 644814 \\
\hline Мінімальний обсяг витрат, необхідний для ефективного системного адміністрування, грн. & 192186,7 \\
\hline $\begin{array}{l}\text { Мінімальний обсяг витрат, необхідний для ефективного управління маркетингом та просуванням, } \\
\text { грн. }\end{array}$ & 792488,5 \\
\hline $\begin{array}{l}\text { Максимальний обсяг витрат, необхідний для ефективного самостійного налагодження та оснастки } \\
\text { обладнання, грн. }\end{array}$ & 2127845 \\
\hline $\begin{array}{l}\text { Максимальний обсяг витрат, необхідний для ефективного самостійного системного } \\
\text { адміністрування, грн. }\end{array}$ & 1311665 \\
\hline $\begin{array}{l}\text { Максимальний обсяг витрат, необхідний для ефективного самостійного управління маркетингом та } \\
\text { просуванням, грн. }\end{array}$ & 3002671 \\
\hline
\end{tabular}

* Розраховано автором 
Використавши для розрахунку оптимізаційної моделі статистичний пакет Maple, знайдено оптимальну кількість осіб, яких слід залишити як працівників підприємства для забезпечення стабільної роботи при передачі бізнес-процесів на аутсорсинг, а саме: налагодження та оснастка обладнання - 3 працівники, системне адміністрування - 2 працівники, маркетинг та сервісна підтримка - 4 працівники.

Така кількість осіб здатна мінімізувати ризики, які виникатимуть із інтеграцією діяльності провайдера та замовника послуг, запобігти витоку комерційної інформації та уникнути інших видів ризиків аутсорсингу, які наводились у попередніх підрозділах роботи. При стабільній роботі протягом певного періоду між замовником та провайдером послуг та максимальній інтеграції їхніх виробничо-господарських процесів можна розглядати подальшу, глибшу інтеграцію і відповідне скорочення працівників у замовника послуг, однак такий процес змін та перенесення бізнес-процесів у межах аутсорсингу повинен відбуватись поступову, особливо на машинобудівних підприємствах із їхньою специфікою капіталомісткості та технологічності.

Висновки i перспективи подальших досліджень. На даному етапі оптимізаційна модель вказує на те, що є змога скоротити кількість працівників у замовника наступним чином: налагодження та оснастка обладнання - 6 працівників, системне адміністрування 11 працівників, маркетинг та сервісна підтримка - 11 працівників. Вартість відповідних послуг у провайдерів в середньому на $25-30 \%$ нижча відповідно економія досягатиме 20-25\% від попередніх витрат на виконання необхідних бізнеспроцесів.

Окрім оптимізації діяльності підприємства замовника аутсорсингу, також повинен бути оптимізований сам процес передачі функцій від замовника до провайдера, при цьому оптимізація повинна відбутися за основними видами ресурсів, насамперед людськими, часовими та фінансовими.

Використання оптимізаційних моделей дає змогу в процесі аутсорсингу мінімізувати втрати та витрати ресурсів, необхідних для ефективної діяльності як замовника послуг, так i провайдера, a також забезпечити результативність процесу передачі бізнеспроцесів від замовника до провайдера послуг.

Подальші дослідження слід спрямувати на розвиток моделей використання аутсорсингу у діяльності підприємств.

\section{ПЕРЕЛІК ВИКОРИСТАНИХ ДЖЕРЕЛ}

1. Бравар Ж. Ефективний аутсорсинг: Розуміння, планування та використання успішних аутсорсингових відносин / Ж. Бравар, Р.Морган. - Дніпропетровськ. Баланс Бізнес Букс, 2007. - 288c.

2. Микало О.І. Підходи до визначення терміна “аутсорсинг” / О.І. Микало // Економічний вісник НТУУ «КПІ». - Київ, 2010. - С. - 111-115.

3. Аникин Б. А. Аутсорсинг: создание высокоэффективных и конкурентоспособных органи- заций : учеб. пособие / под ред. Б. А. Аникина. - М. : ИНФРА-М, 2003. - 187 с.

4. Кросс Дж. Аутсорсинг: British Petroleum's / Дж. Кросс // Гарвард Бизнес-ревю. - 73(3).

5. Кесарчук Г.С. Бухгалтерський аутсорсинг: поняття, види, переваги та недоліки / Г.С. Кесарчук Науковий вісник ужгородського університету, Серія Економіка. - Випуск №1 (42). - 2014. - С. 201-204.

6. Матвій I.Є. Аутсорсинг в діяльності промислових підприємств: основні переваги та загрози / I.Є. Матвій // Прометей: регіональний збірник наукових праць з економіки. - Донецьк: ДЕГІ, 2008. №1(25). - С. 184-189.

7. Бойчук І.В. Аутсорсинг у маркетинговій діяльності підприємств / І.В. Бойчук // Режим доступу: http://www.rusnauka.com/30_OINXXI_2013/Economics/6_147161.doc.htm.

8. Подольчак Н.Ю. Проблеми оцінювання та регулювання соціально-економічної ефективності систем менеджменту машинобудівних / Н.Ю. Подольчак. - Львів: Видавництво Львівської політехніки, $2010,400 \mathrm{c}$.

9. Подольчак Н.Ю., Чепіль Б.А. Управлінські витрати підприємств газового комплексу: адміністрування та оптимізування / Н.Ю. Подольчак. Б.А. Чепіль. - Львів: Міські інформаційні системи, 2014. - $166 \mathrm{c}$.

10. Офіційна звітність ПрАТ «Концерн-Електрон» [Електронний ресурс] - Режим доступу до ресурсу: https://smida.gov.ua/reestr/?kod=13801109. 


\section{REFERENCES}

1. Bravar, Z.H. \& Morhan, R. (2007) Efektyvnyy aut-sorsynh: Rozuminnya, planuvannya ta vykorystannya uspishnykh aut:sorsynhovykh vidnosyn [Effective outsourcing: Understanding, planning and using successful outsourcing relationships]. - Dnipropetrovs'k. Balans Biznes Buks, [in Ukrainian]

2. Mykalo, O.I. (2010). Pidkhody do vyznachennya termina "aut'sorsynh" [Approaches to the definition of the term "outsourcing"]. Ekonomichnyy visnyk NTUU «KPI». - Economic Bulletin of NTUU "KPI", 111-115. [in Ukrainian]

3. Anykyn, B.A. (Ed.). (2003) Aut'sorsynh: sozdanye vysokoéffektyvnykh y konkurentosposobnykh orhanyzatsyy [Outsourcing: creation of highly effective and competitive organizations] - Moscow : YNFRA-M [in Russian].

4. Kross, Dzh. Aut sorsynh: British Petroleum"s [Outsourcing: British Petroleum's]. - Harvard Byznesrevyu. - Harvard Business Review. [in Russian].

5. Kesarchuk, H.S. (2014) Bukhhalters'kyy aut·sorsynh: ponyattya, vydy, perevahy ta nedoliky [Accounting outsourcing: concepts, types, advantages and disadvantages]. Naukovyy visnyk uzhhorods'koho universytetu, Seriya Ekonomika. - Scientific Bulletin of Uzhgorod University, Series Economics, 1(42), 201-204. [in Ukrainian]

6. Matviy, I.YE.(2008) Aut $\cdot$ sorsynh v diyal'nosti promyslovykh pidpryyemstv: osnovni perevahy ta zahrozy [Outsourcing in the activity of industrial enterprises: the main advantages and threats]. Prometey: rehional'nyy zbirnyk naukovykh prats' z ekonomiky. - Prometheus: regional collection of scientific papers on economics, №1(25)., 184-189. [in Ukrainian]

7. Boychuk, I.V. (2013) Aut·sorsynh u marketynhoviy diyal'nosti pidpryyemstv [Outsourcing in marketing activities of enterprises]. www.rusnauka.com Retrieved from: http://www.rusnauka.com/30_OINXXI_2013/Economics/6_147161.doc.htm. [in Ukrainian]

8. Podol'chak, N.YU (2010) Problemy otsinyuvannya ta rehulyuvannya sotsial'no-ekonomichnoyi efektyvnosti system menedzhmentu mashynobudivnykh [roblems of evaluation and regulation of socio-economic efficiency of machine-building management systems]. - L'viv: Vydavnytstvo L'vivs'koyi politekhniky, [in Ukrainian]

9. Podol'chak, N.YU. \& Chepil', B.A. (2014) Upravlins'ki vytraty pidpryyemstv hazovoho kompleksu: administruvannya ta optymizuvannya [Management costs of gas complex enterprises: administration and optimization] - L'viv: Mis'ki informatsiyni systemy, [in Ukrainian]

10. Ofitsiyna zvitnist" PrAT «Kontsernu-Elektron» [Official report of PJSC "Concern-Electron"] smida.gov.ua Retrieved from: https://smida.gov.ua/reestr/?kod=13801109. [in Ukrainian] 